This item was submitted to Loughborough's Institutional Repository (https://dspace.lboro.ac.uk/) by the author and is made available under the following Creative Commons Licence conditions.

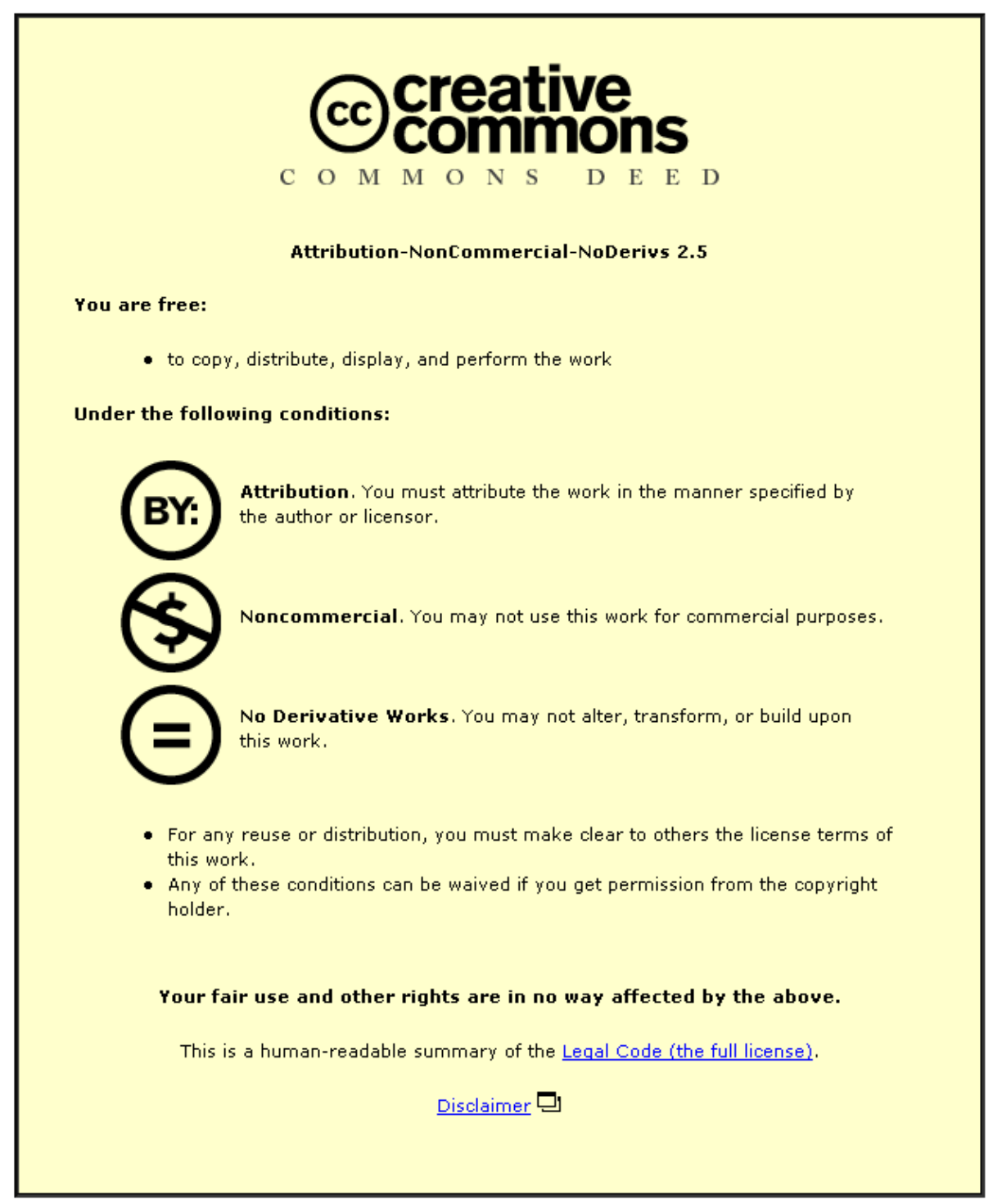

For the full text of this licence, please go to: http://creativecommons.org/licenses/by-nc-nd/2.5/ 


\section{Introduction: Dwelling on Hardy}

Thomas Hardy is at once amongst the most constantly read of novelists of the nineteenth century, and yet, at the same time, the most challenging, misread of authors. He lends himself to popular adaptation, as the BBC's 2008 production of, predictably, Tess of the D’Urbervilles demonstrates. Yet, as faithful as such adaptation—or what I would term 'translation' - might be to the narrative, that which is most arguably 'Hardy' is occluded, if not erased almost entirely. With Hardy (and, indeed, almost any novelist), there is so much which does not translate. In Hardy's case, though, the untranslatable is of greater significance, and so remains, encrypted and in full view, on almost every page. Tess and Jude the Obscure excepted, Hardy's dozen or so other novels receive less attention than is their due (unless by some Hardy critics), and it is in part the purpose of this book to redress that balance a little. To this end, Tess and Jude are given less attention than some might think they deserve, and I explain, without justifying, my reasons for this in the last chapter.

With Hardy, whose texts bear witness to a daunting eclecticism in reading, thought and epistemology, touching on everything from English folklore to the thought of Arthur Schopenhauer and Henri Bergson, it seems all the more important to respect the singularity of the text, in order that we begin to mine that which is embedded so densely, and without which Thomas Hardy is not Thomas Hardy. For this, and other reasons, I have not presented a central argument beforehand in this introduction, concerning the nature of what is to be read in Hardy. In every chapter I seek to respond to that which Hardy's text imposes, to greater or lesser degrees. The result, I hope, is that this volume will be read as having an organic development, in which motifs, tropes, concepts and so on come to reiterate themselves, returning with different emphases, approached from different perspectives, and 
given different degrees of scrutiny. Inevitably, this will result in certain tensions for the reader, which, I believe, are not simply unresolved problems, but rather a response to the paradoxes, aporia, and undecidables which are encountered as that which takes place in the text of Thomas Hardy.

Because novelists are not systematic — not necessarily, not merely systematic —in the organization of their materials, except where the dictates of narrative development and logic demand certain trajectories, it seems inappropriate to explicate one's reading in too schematic or formalized a manner. With Hardy, whose texts bear witness to a daunting eclecticism touching on everything from English folklore to the thought of Schopenhauer and Bergson, it seems all the more important to respect the singular nature of the text. For this reason, I have not presented beforehand a central argument concerning what is to be read in Hardy's text. In every chapter I have sought to respond to that which Hardy's text imposes, to greater or lesser degrees. The result, it is to be hoped, is that this will volume will be read as having an organic development, where motifs, concepts, and themes reiterate themselves, return with different emphases, approached from different perspectives, and given different degrees of focus. In short, this volume is written - if it is produced with any shadowy figure in mind at all-for the good reader of Thomas Hardy, who apprehends how in the phenomena of repetition and return, it is difference and not the same which is of significance. This may result for some readers in a sense of being immersed in an argument, only to find that abruptly terminated, as Hardy determines another direction, or demands another mode of critical perception. Inevitably, this results in certain tensions, which I believe are not simply unresolved problems in the process of analysis (if indeed, they are this at all), but rather that the tensions, paradoxes and concomitant aporia which are encountered, are mediations or translations, if you will, of what takes place already in Hardy's text. 
In proceeding in this manner, I have organized the chapters more or less according to the order in which Hardy’s novels were published. Where I depart from chronological order, this is dictated by the demands of particular novels, their insistence on being heard. In pursuing a roughly chronological order though, from earliest to the latest novel, I am not proposing a development or some seamless trajectory to be read from Desperate Remedies (1871) to Jude the Obscure (1895). I do, however, pursue readings of the texts in this manner in order to work, however silently and in small, local ways, against Hardy's revisionary categories, introduced first in 1895, whereby he divided the novels into three 'sets': 'Novels of Character and Environment', these being: Under the Greenwood Tree, Far from the Madding Crowd, The Return of the Native, The Mayor of Casterbridge, The Woodlanders, Wessex Tales (a collection of short stories, published in 1888), Tess of the D'Urbervilles, another collection of short stories, Life's Little Ironies (1894), and Jude the Obscure; 'Romances and Fantasies', the next category, includes A Pair of Blue Eyes, The TrumpetMajor, Two on a Tower, The Well-Beloved and the collection of short stories, A Group of Noble Dames (1891); the last group of novels, Desperate Remedies, The Hand of Ethelberta, and A Laodicean are given by Hardy the collective title 'Novels of Ingenuity'. Despite such categorization and the logic by which Hardy makes these decisions retrospectively, novels from one group share obsessions and interests with novels from another, and these may be more effectively highlighted in the manner I have chosen.

\section{Dwelling in Hardy}

Between 1882 and 1886 Thomas Hardy published no major work. Having been seriously ill in 1881 when he was forced to dictate much of A Laodicean to Emma, his first wife, Hardy 
moved back to Dorset, in the following year, first to Wimborne and subsequently to Dorchester, when the building of Max Gate, Hardy’s final home, began. A 'Laodicean’ is someone who is lukewarm or half-hearted, particularly concerning matters of doctrine or ideology in religion or politics; the very opposite of Hardy in fact. Yet this, his sixth novel, has less to do with such indecision than it might be said to be interested in interrogating an obsessive ambivalence concerning the relative values of modernity and the past, the ways in which the former persists in the latter, or the manner in which particular members of late Victorian society are driven by a sense of the past. A Laodicean asks a question underlying Hardy's writing: how can the archaic and modern coexist? Is such a thing imaginable, or is it perhaps the case that the constant collision between the traces of the past and experience of the present cause chaos and crisis, precipitating fateful decisions on the modern subject in the face of the undecidable in the historical present?

In Two on a Tower, Hardy forces the old and the new together in a number of ways. A folly built on what may have been either a Roman fortress or a pagan burial mound or barrow becomes the site for the practice of astronomy. However, the origin of the site remains unknown, Hardy informing us of this. Such unknowability or, as Hardy calls it, in an inflection that situates responsibility in human consciousness, 'forgetfulness' (TT I.I.6) extends to the origin of the faux-Tuscan tower itself, as 'Probably not a dozen people within the district knew the name of the person commemorated, while perhaps not a soul remembered whether the column were hollow or solid, whether with or without a tablet explaining its date and purpose' (TT I.I.6). Certainty concerning the past, along with matters of verification and authenticity, cannot be gained. What this yields is the confrontation, through the latest astronomical technology, with an undecidability in the face of the limits of human knowledge, culminating in nothing less than the ageless age of the universe, its temporal abyss. With that arrives a 'coming-to-consciousness' for astronomer Swithin St. 
Cleve, possibly Lady Constantine, on whose estate the tower is situated, and perhaps for the reader also: the most singular 'modern' understanding is the absolute insignificance of human perception when confronted with the apprehension of the abyssal and the infinite. If the light that reaches us comes from a star already extinguished, in effect we are receiving that which only remains as a trace, and which no longer exists as such. This being the case, we glimpse in the abyss our own-having-become-extinct.

What to do in the face of this appalling recognition except to stop writing perhaps, as does Hardy? Admittedly, this is merely hypothesis, a convenient fiction structured by the equal convenience of hindsight in collusion with the force of narrative. However, in reading or 'inventing' this creative 'hiatus' as a place from which to start a study of Hardy, what one is given to read in the literary silence of Hardy is the possibility that there is a secret at the heart of his writing. Such a secret is not necessarily recuperable. It cannot be unearthed as such. Yet, the secret of Hardy is everywhere in his writing. It moves in different eddies; it flows throughout his narratives as an inevitable, and invisible force shaping novel and poem alike. A late poem such as 'Silences' (CP 865-66), from Winter Words (1928), captures the persistence of the secret, in its repetition of the different silences that inform place, silence being the signifier of a present haunted by memory. Of the various silences, the silence of the house is the most strident in its call; for it brings to the poet's mind the human past, of lost songs, 'music-strains', the sounds of friends-all in fact that constitutes for Hardy the experience of what it means to dwell ${ }^{\mathrm{i}}$ as a being conscious of one's material existence on the earth, rather than simply to exist. Hardy, we might say, dwells on dwelling, as both material existence and a privileged metaphor for the one's being as it bears the burden of memory. As Hardy has it: 'we two kept house, the Past and I' (CP 308-309; emphasis added). In 'Silences', the work of memory, figured through the silence, has powerful properties; the silence transforms the house into a 'tomb' and, therefore, the merely living witness into one 
who is more truly dead than those who are simply deceased. Mourning and memory, closely interlinked here, are the proper work of literature for Hardy, and both are caught in a web with the question of what it means to dwell on the earth.

Hardy's 'secret' has to do, therefore, with dwelling, not as a given place or structure, but instead as the manner in which human beings exist historically and culturally. Reflecting on dwelling in a philosophical sense given it by Martin Heidegger, I would define dwelling in the following manner: to dwell means to orientate oneself with regard to one's being, and the historicity of being. Mindful merely of the modern or the present, one forgets the true nature of one's being, and so one's dwelling. This is the 'secret' that each of Hardy's characters and his narratives seek to negotiate or by which they are confronted in moments of crisis and contretemps. Hardy's 'secret' is thus marked on the text through the amaterial-neither material nor immaterial in any simple empirical sense - traces or remains that inform, shape and determine action, identity and the historicity of any present moment. Silence gives the world if not meaning then a place for meaning to be inscribed. It thus gives meaning to human apprehension, even if that understanding is of one’s true self bereft of any theological or metaphysical comfort. This gift bears in it the double bind, then, such a gift being given at a price. This is the sense for Hardy that dwelling is marked indelibly with a necessary material and historial finitude: figured in the loss of sound, and the space concomitantly opened by silence in 'Silences'. In this space onto will be written significance for the reader, who bears witness to that silent space. Such loss acknowledges the historicity of being itself, and with that the inevitable finitude by which being is informed.

Winter Words is the work of an old man aware acutely of his own mortality. It might be argued that a sense of one's finitude, however indirect or implicit in a poem which mourns loss and records silence as the place in which memory gives shape to one's phantasms, and which spectres, in turn, illuminate the nature of being, is inevitable. Nevertheless, it is not 
mortality that is troubling. It is the burden of memory, and with that, the inescapable sense of the extent to which one's being is bound up with this responsibility in relation to the act of dwelling; dwelling not simply in a place, at a given time, but dwelling as consciousness, as specific and reflective singular consciousness of the ways in which being and dwelling, though non-synonymous, are interchangeable.

Were we to consider briefly each of Hardy's novels, the interest in notions of being and dwelling, the traces of the past and the materiality of modernity, the role of memory and the responsibility of story-telling, all are seen to inform a vast and complex web, a generative matrix that performs even as it questions what is for Hardy the modern condition in the 1880s and 1890s. Whatever the particulars of such singular narratives, however, each may be read as coming down through particular perspectives to an interrogation of the meaning of being and what it means, moreover, to dwell, if being is, in its reflective consciousness and responsibility for the remains of the past, a mode of dwelling. It should come as no surprise therefore to reflect on the fact that, while 'Silence' is one of Hardy's last poems, one of his first extant works is also a poem concerned with the idea of the house, dwelling and memory: 'Domicilium' (CP 3-4). Of this first poem, it is perhaps worth noting, at least in passing, that the very title, the Latin for dwelling place or place of habitation, marks and remarks itself with both distancing irony, historical anachrony and untranslatability (the loss, or breakdown, of communication). There is a sense of something foreign in and about the idea of home. There is a foreign guest if you will, and an apperception also of what haunts the familiar, of what disturbs in the most familiar location, home. The unfamiliar, the strange, returns from within the most familiar locations. A dead language, Latin, defines home and, in being this trace of the dead, signifies that which is always unassimilable, irrecuperable, and other. A title in another's tongue, it remains on the page as a boundary resistant to domestication, as well as a threshold one will never cross. At the same time it also signals through the trace of 
Introduction

the tongue the historical colonisation of England. Its trace remains, then, as a remainder of the ghosts of the past, of history itself as a history of colonial possession and dispossession, and, in that one word, a history also of place, of the historical event taking place, and of displacement. The present home, with identity familiarly defined through place in the present, is always interrupted in this fashion for Hardy. It is always troubled by a communication from some other time, some other place, which has fallen into partial or complete ruin and untranslatability, and yet which is intimately bound up in that which gives identity a home, and which makes us who we are.

From the title to the poem: first published in 1918, it was, we discover from a note written by Hardy on the occasion of a private printing given to Florence Hardy, written 'somewhere between the years 1857 and 1860, while he was still living with his parents at the charming cottage described in the verses, the birthplace of both himself and his father' (SP 248). A poem beginning with a representation of a present scene, opening out from the cottage to a description of the immediate landscape, it moves back, at the beginning of the fourth stanza, to a past of 'days bygone_-/long gone' and 'my father's mother'. Memory presents the scene to the mind's eye, bringing to light and thereby illuminating the moment with another representation folded inside the present poem, and the present of the poem. Hardy thus recollects his younger, other self but in dwelling on that memory, calls forth another, still older scene, by which the present is haunted, by which it is touched, and which remainder of the past continues to touch in the present, thereby maintaining the connection. This in turn is opened from within, in a moment of potentially abyssal unfolding and revelation as the grandmother's voice emerges, recorded on Hardy's memory as if it had left an impression like a stylus on wax, but here given amaterial prosthetic projection, to enact its own anamnesiac witness to a past fifty years before Hardy's childhood: 'Fifty years/Have past since then, my child, and change has marked/The face of all things'. Dwelling as 
reflective memory and dwelling as existence in a given location, on the earth, in which past and present, earth, sky and existent being are connected, come together through the act of witness that is literature. But attestation does not offer closure. From within representation, from within the stable and supposedly fixable image or snapshot, the self is exposed to the memory of the other, who returns to open yet again another memory, and with that let in, through the rift in the present, the remains of a past otherwise inaccessible. This is what is understood as authentic dwelling in Hardy's text; and this is Hardy's secret.

\section{Hardy, Who He?}

All questions concerning being and identity give one pause to reflect: Who was Hardy? Who is Thomas Hardy, today? Is it more accurate to speak of him as a poet or a novelist, a poet who wrote novels and short stories, or a novelist who happened to write a great deal of poetry, some of it of the very finest in the English language? Is he a Victorian author, properly speaking, or, conceivably, a modernist, albeit one avant la lettre? Or is Hardy someone who, working always in 'some other's accent' (to employ a phrase of his), remained throughout his life, and subsequently, anachronistic, other to his times, and, still today in ways we have yet to fathom, to ours also?

These questions have much currency currently and in recent years amongst the more 'philosophically' inclined scholars of Hardy. They circulate especially amongst those with interests in interdisciplinary approaches to literature and for those who, through engagement with literary theory in the past couple of decades, have come to recognise that what were previously perceived as 'aesthetic flaws' in Hardy as a writer by earlier generations of critics are not flaws at all, but rather the signs of a writer whose practices cannot be gathered conveniently or comfortably under conventional categories of appreciation. Taking such 
Introduction

questions as my cue, and coming to such points of interrogation from a number of philosophically and historically inflected perspectives anticipated by Hardy's text, I want to continue such work in the present volume.

However, it is not my intention here to address all of Hardy’s work. I can do no more than sketch some possible directions for reading Hardy, and reading him differently—or let us say, reading the difference in Hardy. In reading this difference, I will seek to move in and out of a range of texts, primarily the novels, but also a poem or two. Taking up passages or motifs, recurrent figures and tropes, I will strive to read Hardyean difference with an eye to the writer's modernity. Hardy’s modernity, irreducible to modernism, and so anachronistic to the futures of English literature as well as its pasts, is a modernity of ideas; through this, Hardy explores how the novel might become a poetic vehicle for exploring the abstract, the epistemological, even though this exploration is always grounded in materially recognised conditions of being, historicity, and subjectivity.

In order to gesture towards such an understanding, this book will be most appropriately apprehended as a preface of sorts, a preface to Hardy but always in his wake, not yet having caught up with Hardy, as well as an invention of the Hardyean text, an invention that does not create anything new so much as it finds what is already thereHardy's 'secret', if you will. This introduction will suggest we apprehend Hardy's text as an archive, and a very peculiar archive at that. Hardy’s text offers readers an archive of secrets, secrets concerned with who we are, what it means to exist as beings with self-conscious awareness of their own modernity, their historicity, but cut off from 'true histories' or 'true narratives' of collective, northern European and Anglo-Saxon identity. Hardy's writing is, then, the writing of 'mythic...[or] poetic narrative belonging to the age of psychoanalysis' (Derrida 1986, xxxiii). 
Reading Hardy presents us with more than the difficult apprehension that a writer may generate narratives inscribed out of different times and different modes. The other 'problem' for the reader of Hardy is succinctly captured here:

If individual close readings are unsatisfactory, so are attempts to survey the whole and organize it...by noting similarities from poem to poem and generalizing on that basis. One of the themes of Hardy's poetry, as of his fiction, is the uniqueness of each moment of experience, as well as of each record in words of such a moment. Each moment, each text, is incommensurate with all the others. To...begin to make grand interpretative patterns...is to perform just the sort of falsifying simplification that the poems themselves repeatedly warn against. (Miller 1985, 270-71)

Accepting the logic of this statement concerning the poetry and fiction, this has ramifications for responding appropriately to Hardy's writing practices, his poetic and narrative performances. Given the unsatisfactory nature of close readings on the one hand, and the thematic or other holistic attempts to organize and so generalise on the other, I propose to proceed through a series of readings of moments of unique experience, without the assumption of grand interpretative patterns. Each of the following chapters will risk, nevertheless, the opening of such readings through commentaries on, if not themes, then iterable motifs or structural and epistemological recurrences in Hardy. In each case, I will read such moments as they operate in their singular fashion. I will explore how events and places in Hardy haunt because, whilst they are unique, they bring with them the recognition that this or that particular event has happened in different ways and will continue to take place. Places particularly are invested with impersonal memories, and without that possibility of recurrence and return, the unique or singular moment would not be understandable as an event, the sign of a crisis or irreparable transformation. 


\section{Hardy’s Many Returns}

Of the fourteen (or fifteen) novels written by Hardy between 1871 and 1897, nine were published between 1871 and 1882. My equivocation is deliberate; it is not that I cannot count. The 'last' novel, The Well Beloved (1897), though published after Jude the Obscure (1895), was first produced in a significantly different version as The Pursuit of the Well-Beloved (1892). Even such a revision of a work is suggestive. It indicates a restlessness within the author himself, a tireless and perhaps obsessive desire to work through a range of interrelated themes, images, tropes, narrative trajectories and interactions. After 1882, Hardy completed no more novels until 1886, when he published The Mayor of Casterbridge. This novel, produced at the end of Hardy's return to Dorset, to his home, and to both a new house and also a location in which the Hardys had dwelt for generations, appears to signal the 'return of the native': the return, on the one hand, of the native of Dorset to that county, and, on the other hand, the return of what is native in and to Hardy, that which, as so many remainders of the past dwell in him and, through him, in his writing. Hardy's novel writing career is marked in innumerable ways by such signs of recirculation, revision, supplement, and a desire to find the appropriate expression and appropriate frame for particular themes, motifs, and obsessions, if this is not too strong a word, which take on material form, and which become reiterated throughout his career. There is an incessant drive within Hardy’s writing to return to that which is elusive, that which haunts the writer from the very start, and which comes back to push him to the revision of the same and the invention of what is found to be always already there.

Though not in any ostensible fashion concerning itself with the themes or interests of what is conventionally referred to as fin de siècle fiction, Hardy's fiction also remarks over three decades the sense of endings, of passage and passing away, of irreparable 
transformation, translation and, if this is not to put it too strongly, an apprehension of becoming-posthumous intrinsic to the identities of many of his 'Victorian' readers, whether or not this was felt the part of some of his audience. Hardy's fiction, if it turns to the past and is haunted by the past, is also a fiction haunted by the anxiety of eschatological trauma. To give this another perspective, Hardy, in being at variance with the sociological or sensationalist preoccupations of his literary contemporaries in the last twenty years of the nineteenth century, manifests the ability to speak or, respond to certain deeper, older currents of Englishness, outside the urban, imperial mainstream. Such flows, as those already alluded to, belong to no one era or epoch, but shape the discontinuous narrative of national identity in numerous ways. And all flows tend towards the assumption that the present too will pass into obliteration, as is the inevitable and cyclical nature of human existence given social manifestation.

Despite the exigencies of reception and misperception, Hardy's novel writing career spanned a generation, the last thirty years, more or less, of the nineteenth century. But of Hardy’s 'generation': how are we to locate Hardy, albeit in somewhat adumbrated manner, according to the idea of a 'generation'? Were we to speak with any confidence of 'Hardy's generation', it is worth observing in passing that, not least amongst those who comprise this generation include Emmaline Pankhurst, Sigmund Freud, Friedrich Nietzsche, Gerard Manley Hopkins, Rhoda Broughton, Robert Louis Stevenson and Henry James. Historically, Hardy's generation witnesses the second and third Reform Acts (1867 and 1884), and the establishment of the Fabian Society, the Prime Meridian and Greenwich Mean Time (1884).

A list can give only the barest sense of a culture and generation, however. If anything, the identity of Hardy's generation, considered in the context of a reflexive modernity ill at ease with directions towards a future it could not control, became marked by an insistent sense of turning backwards, looking over its shoulder at a catastrophic rupture, by which the 
Introduction

past was inheritable, knowable, only in ruins, if at all. As the nineteenth century 'progressed', so the signs of cultural anachronism intrinsic to a sense of modern identity were being registered in different ways, from the early modern influence on the Pre-Raphaelite Brotherhood, the fascination with all things medieval as expressed through the poetry of Tennyson, the Arts and Crafts movement of William Morris, to the neo-Gothic architecture of Pugin and his followers, and elsewhere. Cultural anachrony becomes that by which the Janus-face of Victorian modernity is recognised, and Hardy inherits to a great extent the representational economy of a generation haunted by the traces of the various pasts it seeks to aestheticize, dehistoricize and therefore master.

By virtue of generational logic, Hardy must therefore appear as the 'child' of this previous generation of cultures and authors. By the time that Hardy's career as a novelist began, Dickens was dead, as was Elizabeth Gaskell. Hardy’s contemporaries experienced and interpreted the world in radically different ways from their predecessors, and while Hardy ploughed very much his own furrow, yet, at the same time, his experience of the difference between himself and others of his generation was haunted by traces of earlier experience informing his perceptions. This may sound paradoxical, but it is the spirit, if not the essence of late Victorian modernity, which in many ways Hardy embodies more intimately than many of his contemporaries. It is perhaps the reason why the reception of his work by his contemporaries is so fraught, so often misread, and why, conversely, so much of his fiction writing addresses past scenes and the traces of more distant pasts within any single narrative past, as haunting, disruptive forces.

The question of Hardy's generation is caught up with what Tim Armstrong has described as the Victorian subject's 'entry into history, the trauma of becoming-historical which is central to nineteenth-century conceptions of the historical' (2000, 2). Such an entry, and the trauma that accompanies it, is for me the sign of an irreversible, epochal generational 
change. The trauma of material being as a becoming-historical is illustrated powerfully in The Trumpet-Major and Under the Greenwood Tree, two strikingly different, singular texts. Hardy is, then, two novelists at least. Arguably, he is the last properly 'historical' novelist of the nineteenth century, whilst also being the first novelist of a phenomenologically inflected self-conscious apprehension of being's materiality and historicity. His works are central to our perceptions of a world in radical transition, as well as being testimonies to the ghosts of memory, as will be witnessed in the example of The Trumpet-Major. Much fin de siècle fiction might be read, arguably, as an escape from what James Joyce was to call the 'nightmare' of history. Hardy faces this nightmare, however, and presents us with narrative histories of a ghost-plagued culture. While the other novelists might speak, directly or obliquely, to aspects of national identity and subjectivity that are supposedly modern in the nineteenth century in a manner that obscures rather than foregrounds any self-consciousness about one's historicity and modernity (modernity being conceived as the tension between temporally distinct senses of self and other in contradistinction to the historical sense of organic continuity), Hardy, of all writers in the nineteenth century, engages most unflinchingly with 'the way in which the self is constituted by and writes itself into history', without any overt signs of the modernity of being (Armstrong 2000, 2). This is not to say his largely phenomenological interpretation of subjectivity and being is not thoroughly modern. It is. In Hardy's worlds, the modern experience of the self is not focussed through the desire to separate present and past, self and other, but to realise the self as a product of the irresolvable tensions that such binaries produce.

\section{Keeping House}


For Hardy, the past is always with us, however hidden its traces, however encrypted its signs. And concomitantly, any writer of the modern age must respond to such signs and address them through a language that suspends time for the reader in different ways, so as to call attention to matters of visualization, perspective, and focalization. This has less to do with a distance from past generations and the assumptions about modernity accompanying those perceived or desired acts of distancing, than with an apperception of the subject's irreparably being-riven, being-haunted. In this condition Hardy places his characters, wherein, always already displaced from any genuine sense of self and repeating however differentially the actions of generations and cultures before them, they serve to symbolize that anachronic condition of being at the end of the nineteenth century, already noted.

Not a few of Hardy's novels situate their events at a generation's remove, or at a distance of a couple of decades at least from the time of their writing. Yet, somewhat discordantly and anachronically; as, we might say, reading so many signs of the times, the experience of reading them is markedly 'modern', self-conscious, their narratives not necessarily being of their time. A novel such as The Return of the Native (which indirectly dates its specific inaugural action as taking place on November $5^{\text {th }}$, 1842 , from the evidence of the first line of the first chapter, and another reference in Chapter Three) has been read in terms of its modernity, through its meshing of Darwinian and Arnoldian discourses. The very modish or evanescent temporality of such cultural and scientific discourses, themselves so markedly 'Victorian', is nonetheless subsumed within and offered a somewhat stark countersignature not only of the inhuman and initially ahistorical world of Egdon Heath; they are also juxtaposed ironically by the countersignature of older pre-rational or pre-modern cultures. In this, itself a reiterated and iterable structure with singular variations from novel to novel to greater or lesser extents, Hardy presents a world of simulacra and unstable identities, 
a world made up of numerous forms and manifestations of often thwarted or misdirected communication, and which present is rendered partly incoherent by the ghosts of the past. Whatever signals there are by which Hardy's characters attempt to communicate with one another in any given narrative present moment, such signals often go awry. They do so for two reasons: on the one hand, in a modern world everything appears to connect to everything else in a vast web of communication and information; on the other hand, such signals rarely connect or communicate unproblematically, and their delivery is hardly ever timely or on time. There is always in Hardy's writing an errancy in the destination of messages. The other reason for the breakdown in transmission is that, while certain types of signal are unreadable by virtue of their being anachronistically present, the signals are so many and so frequent, and the frequencies of transmission so variable and multiple, that there are interruptions in transmission and reception. Hardy's world is one troubled by a density of signs, and the interruption of signification as a result of the density of the flow.

Hardy's world is also one in which there is repeatedly a confrontation with anachronic spectres inhabiting the real. Hence, as a result of the tensions and gaps produced out of the spectral and material, the past and present, the anachronistic and the modern, we are given to read the signs of a 'particular kind of historicity...[which] is opened up here, painful and elegiac, even as it is inevitable and progressive' (Armstrong 2000, 4). Such historicity finds itself insistently caught up in the communication of the inability to communicate, so densely insistent is the web of signs from out of which 'modern' society finds itself woven.

Hardy's Wessex, with its various 'worlds' and 'times' give temporal and historical perspective on such moments of historical trauma. His worlds are as much haunting as it is haunted, and this is given particular expression in The Mayor of Casterbridge, but is registered forcefully in most his novels. To approach the question of what haunts Hardy, and to supplement the sketch already given, I propose to pursue in this volume the relationship 
Introduction

between historicity, reading and misreading, perception and the phenomenological self, which I take to be at the heart of Hardy's writing. At the same time, this will necessitate questions being raised in passing concerning discourses of sight, perspective, perception, and vision. The problems of perception and reading one's historically determined subjectivity through acts of reading the signs of past cultural moments that accumulate in the fiction of the self inform all Hardy's texts. In a different manner, this question of what haunts reading and reading as the haunt of the unreadable is also the problematic of generational position. Hardy does not belong to the previous generation, by virtue, obviously, of the accident of when he is born but also, more importantly, because of a pronounced epistemological difference between the way the previous generation's perceptions of being, historicity and representation are shaped and Hardy's own. However, this does not mean that Hardy belongs to his own generation. He, or at the very least, his text is other than those times. The misreading of cultural signs, the traces of the past, and the pulses of cultural memory, therefore inform the critical misreading of Hardy in both his own time, and in subsequent generations.

Returning briefly to the question of who we think Hardy is or was, then, it is perhaps best to turn to Hardy's poetry where the question of Hardy's historical or generational 'home' comes most acutely to the fore. From 1898 until his death, Hardy published poetry continuously throughout the first three decades of the twentieth century, editing the Wessex edition of his novels in 1912. In all Hardy wrote and published eight volumes of poetry during his lifetime. It is a salutary point in any sketch of English literary and cultural history to recall that, when Hardy died, many of the now canonical works of modernist literaturefor example, Pound's Hugh Selwyn Mauberley (1920), Eliot's The Waste Land (1922), Joyce’s Ulysses (1922), Woolf's Mrs Dalloway (1925) and To the Lighthouse (1927)—had already been published. 
Even such a baldly factual statement alerts us therefore to the problem of placing Hardy; with that, the double-question of historicity and anachrony is raised once again. To rephrase this, does Hardy have a proper home? Where, in literature, might his texts be said to dwell? G. R. Elliott observes as early as 1928 how Hardy's publications belong to two different times simultaneously, one a forensic modernity of the 'laboratory', the other, the time of ghostly folklore and related, haunting atavistic traces $(1928,1185)$. Yet, surely one cannot dwell in two different times? The time that is absent for Elliott in the production of Hardy's clinically precise yet phantasmagorical world is that of overwrought nineteenthcentury melodrama. Hardy's work, Elliott avers, 'is far from theatric', moving with a 'sincerity and simplicity' (1185) that, once more, is scientifistic and fetishistic in its attestation. Scientifistic and fetishistic: more modern than modern, and yet strangely superstitious, primitive. Like his near contemporary, Sigmund Freud (1856-1939), Hardy does not quite belong to any one epistemological or generational locus. Dwelling in the margins, as it were, Hardy, like Freud, cannot do away with ghosts even if he cannot quite believe whole-heartedly in their possibility, the possibility of the impossible. Hardy's 'secret' is this conjoined inability and desire. To put this another way, Hardy's 'modern' world of trains and telegraphs, the post, steam ships, astronomy, geology and photography exists uncomfortably alongside a collective and yet temporally heterogeneous and incommensurate field, as, in a 'decomposition' of the present moment, we come to read again and again of 'figures and tropes', which, belonging to times other than our own, 'cannot be subsumed by...a coherent configuration of meanings' (Plotnitsky 2001, 83). Such figures can be missed, or overlooked. But in every case, how Hardy considers and presents the world resists aesthetic formalization, and so disturbs our reading habits. It is for this reason that I turn to the reception of Hardy. 
Introduction

\section{History and Memory, Material and Immaterial}

Hardy's sense of many subjects, but most especially time, historicity, temporality, and the role vision, narrative, representation and memory play in relation to the temporal and historical, is complex and often apparently contradictory. It is as if there exist, as a coterminous mode of staging in most if not all Hardy's writings two worlds, two times, each of which threatens the other, as an intimate and yet violent alterity. Concerning the function of memory in relation to the material world, 'Hardy's observations about the mental traces we leave upon the material world register a disparity between the fleeting nature of human consciousness and the comparative permanence of inanimate objects' (Vrettos 2007, 199): Between, that is, the material and the immaterial there is signalled the reflective experience of one's own being, neither one nor the other, and yet mediating both, as the amaterial. One’s being is transitory, brief, and consciousness reminds us of that, even as it causes us to reflect on the material permanence of the world in which we exist. This leads to a question: what, exactly, 'does it mean for an object to be "saturated" with human memories? What kinds of traces might “thoughts and glances” actually leave on the material world?' (Vrettos 2007, 199) Such an interrogation is invaluable for expressing economically everything that takes place in Hardy. We can see those persistent obsessions in the first pairing of notes in Hardy's 'Facts' Notebook. They may not answer the questions, but they do, undoubtedly, throw Vrettos’ important commentary into sharp relief:

The landlord leases land more \& more frequently to capitalist farmers - the class of yeoman arise-Farmer dependent on his hay \& straw for his winter keep. Cattle \& sheep were fattened in summer \& killed at its close, their flesh being salted for winter use-_Summer is y-cumin in,” meant much more in those days than it does in ours on this account. Sheep farming takes the place 
of agriculture-vast enclosures are made from the common field, wh was the chief cause of Ket's rebellion in $1549 . .$.

Families of the ancient Saxon \& Norman race-either extinct or reduced to the lowest fortune-Could one of those illustrious shades return to earth he might behold one of his descendants dancing at the lathe-another tippling with his dark brethren of the apron... a fifth poaching upon the very manors possessed by his ancestors. (FN 3-4)

Together, the passages can be read as opening onto the possibility of a mode of narrative that is at one and the same time visionary and historiographical, grounded by the remains of material cultures undergoing often irreparable transformation. These assume through translation a sufficient distance, as much epistemological as it is historical, so as to be either partially unreadable or wholly ignored by many in the present (save Hardy, of course), However, their traces leave a certain resonance in play so as to inflect the present in such a manner that a decisive and disastrous effect is produced, a crisis or similar irreparable event, precisely because the subject or subjects in the present no longer know how to read. On the one hand, there is, in the first passage, above, a telegraphic précis of a review, taken from the Spectator in July 1883, of a book concerning the history of English agriculture. Specifically, Hardy has sketched a note concerning the effects of the Enclosures Acts, and the rise of 'capitalist farmers' (FN 3). On the other hand, the annotation in the second is a summary from John Fitzgerald Pennie’s (a fellow countryman of Hardy’s from East Lulworth, Dorset, but belonging to Hardy's grandparents’ generation) The Tale of a Modern Genius. Pennie’s Britain's Historical Drama may have been an influence on the writing of Hardy's The Dynasts by (Millgate 1994, 316). But whether this is so, Pennie provides Hardy with much information about 'families of the ancient Saxon \& Norman race...[who, by the 1880s are] either extinct or reduced to lowest fortune' $(F N 3)$. We might also note how the 'enclosures' of the one note produces, historically, the poachers of the second. 
However, as the note continues, another invention is expressed: 'Could one of those illustrious shades return to earth, he might behold one of his descendants dancing at the lathe-another tippling with his dark brethren of the apron...a fifth poaching upon the very manors possessed by his ancestors' (FN 3-4). Between these two extracts from the Notebook a representation is to be read of Hardy's many narrative interests: rural political and social history; the effects of power and the transformation in the lives of people otherwise un- or under-represented historically, except as its subjects or victims; the imaginative sympathy with the chance, as well as systematic effects of historical and cultural change; and the apprehension of anachronic occasion in the possible communication or historical arrival at consciousness between the spectres of the past and the material circumstances of the present. Indeed, it might be risked that, between the two notes, we witness being woven and unravelled the matrix from which Hardy’s fictive comprehension and presentation of modern English identity is generated. To go further, Hardy's presentation is performative. The crisis between self and world, self and other, habit and defamiliarization, modernity and the archaic are not simply observed, represented or otherwise commented on in some masterly control of mimetic delineation. Instead, figures and tropes, metaphors and inanimate objects play within consciousness, performing the very experience of late Victorian consciousness, in a manner that bypasses individual consciousness of any given character, to become the movement of narrative itself, as dialect words, overly ornate Latinizations, and 'deformed' grammatical structures contend. There is thus enacted across Hardy's writing an iterable and mobile structure of presentation, which, though unfamiliar in one sense, nevertheless maps one's encounter with the world, in which relations between dissimilar and otherwise incommensurable tropes, images, languages, experiences and events become bodied forth in Hardy's modes of representation. 


\section{Taking Back Hardy}

While the internal logic of relation without direct or obvious connection or relation is in some manner unequivocally and forcefully there on nearly every page, Hardy's anachronistic intermixing of cultural traces must have made him appear to some of his own generation distinctly quirky, when compared with, say, a Wilde, a Gissing, or a James. As a result, Hardy was not well served by readers of his generation. A strange disjunction forms therefore around the reception of Hardy. On the one hand he was and has remained undeniably popular. He was and is much read, if not well read. On the other hand, critical voices have found themselves at pains to explain Hardy, often through their failed efforts at aesthetic formalization, becoming disquieted by what his work 'does' in the house of English literature, a domicilium if you will to which critics believe they hold the key, and with which they believe themselves to be familiar, which house it is their habit to guard.

For many years, during Hardy’s lifetime and subsequently, after his death in 1928, there has been expressed repeatedly a sense that Hardy has been misread. For example, Terry Eagleton offers the following potted history of Hardy’s reception:

Not all that long ago, a standard account of Thomas Hardy might have run rather like this: Hardy was a self-educated author who struggled his way up from the ranks of the common people, and wrote gloomily fatalistic novels about an English peasant society whose traditional way of life was being undermined by external urban forces. (Eagleton 2005, 187)

He then proceeds: 'Not a word of that account is in fact true, except perhaps for [the definition of Hardy as an] “author”, and to inquire why not might lead us to a more accurate understanding of the man and his fiction' (Eagleton 2005, 187). While it is not my intention to inquire 'why' exactly, yet it is necessary, nevertheless, to begin any critical engagement 
with Hardy's text with a consideration of the problem of 'Hardy' qua canonical literary figure, as this problem is articulated through criticism's misperceptions. Though I will not be examining many of the analyses that 'get Hardy wrong' to greater or lesser extents, I will offer a sketch of the failures and avoidances of reception in brief broad strokes, in order to indicate the silences and ellipses to which we ought to attend.

It might be asked why this should be worth our interest. Although Hardy criticism has done a great deal in the last two decades to counteract the hitherto prevailing tendencies in misreading Hardy that Eagleton outlines, that he can write this with any justification in 2004 hints at the extent of the work to be done with regard to reading Hardy aright. There is still much to be done to become the good reader that Hardy desired, if his own comments on the nature and purpose of fiction, or the reception of his works as he recounts this history in The Life of Thomas Hardy are anything to go by. Possible correctives to the 'avoidance' of reading and the history of misreading that Eagleton signals, which, in the author's own lifetime, caused Hardy to abandon novel writing, remain necessary and to come.

Of the tendency towards non-reception and as a sign also that Hardy was anachronistic to his own time, Donald Davidson has remarked that there 'was a real intellectual distance between [the author]... and almost three generations of critics' (Davidson 1940, 163). As Davidson continues, 'critics have not so much underrated—or overratedHardy as missed him' (163; emphasis added). This has come about, according to the critic, inasmuch as those generations of critics were misled, continuously and repeatedly, 'by the superficial resemblance between [Hardy's] work and the product current in their day'. Yet, as Davidson concludes, 'though Hardy was in [his] time, and was affected by its thought and art, he was not really of that time' $(1940,163)$. It is therefore clear from this commentary not only that there are the traces of anachrony in Hardy's writing, but Hardy himself was anachronistic, as it were, out of joint not exactly with the times in which he found himself but 
rather with the tenor, the dominant discourses of the day, and with that, at odds with the hegemonic cultural, aesthetic representational logics.

Beyond those three generations of critics (Davidson’s article was published in 1940), Hardy continued to be 'missed', as it were, the delivery of his text deferred, gone astray, delivered to the wrong address. Eagleton identifies four 'distinct stages' in the development of Hardy criticism on which we have already touched $(1981,127)$. The first two phases read the novelist as 'anthropologist of Wessex' and, subsequently, 'the melancholic purveyor of late nineteenth-century nihilism’ $(1981,127)$. This particular assessment at least accords Hardy a certain comprehension on the part of the reader with the difficulties Hardy encountered in seeking to transcend what he called 'the analytical stage', which he felt novel writing had reached by the 1880s (LTH 183). Moving beyond this early assessment of Hardy, Eagleton describes the response to Hardy in the post-war years. Formalist criticism of the 1940s and 50s reads Hardy's work as 'irreparably violated by ideas'. At the same time, there begins a shift towards ‘a more “sociological” reading of Hardy’ (Eagleton 1981, 127). This latter phenomenon is not, however, unproblematically positive for Eagleton. For, as he argues, much of such criticism focused on what it took to a safe vision of a lost rural England appealed to by Hardy in sentimental and mythological terms, while also criticising Hardy for the oddities of his language and style, a critical tendency persisting into the seventies (1981, 127-28). Peter Widdowson also encapsulates the 'problem of Thomas Hardy', alerting us to a selective critical reading of the novels aiming to discern a 'true' Hardy who can be made to belong comfortably to the literary canon, while leaving aside those novels which are read as 'exaggerat[ing]' perceived 'flaws' to be found throughout Hardy's narrative oeuvre. This involves detecting the “improbable” use of chance and coincidence, "flat” and "stagey" characterization, melodrama, and an obtrusively over-elaborate style' in the 'critical fashioning of the “true” Hardy’ (Widdowson 1998, 75-76). 
We might say, then, that criticism of Hardy falls into two camps. On the one hand (to risk an overworked formula), it attempts either directly or indirectly to stay the complex and resistant texture of the novels through readings of them principally as character studies. On the other hand, there is also the reading, produced most frequently in the 1940s, 50s and 60s, though still in evidence in some more recent critical studies, which operates more or less thematically, isolating sociological, contextual, or tragic aspects. Reading Hardy's novels as social history or for the influences of Greek or Shakespearean tragedy provided a thematic path, which, in being thematically driven, tends, as with the readings of character, to avoid other aspects of the novels that problematize and dismantle undifferentiated ontologies of meaning. Academic criticism of the novel has thus conventionally stressed, imposed and returned to particular kinds of readings, and this critical legacy has been difficult to leave behind. Reading and its avoidance have been motivated primarily through discussion of those harmonious elements identifiable as 'tragedy, character study', along with the reception of the texts as more or less 'realistic representation[s] of places, practices and "peasants”' (Keen 1998, 128). Such insistence has been pursued often in conjunction with that critical perception that aesthetically or ontologically Hardy's writing is, once more, awkward or deficient, that it is marked either by a lack or excess with regard to 'proper' modes of mimetic or realist novelistic representation.

Yet it is precisely in the affirmative resistance of Hardy's writing, in its fractured, heterogeneous nature, and its refusal to be read as a seamless, coherent, and unified form; in those narrative energies which insistently and repeatedly assert themselves, that the demand to be read aright is inscribed at and beyond the limits of critical aesthetic ideology. Allied to this, the anachrony of modern identity and its pervasive apprehension of being haunted by the traces of its past others is, itself, the mark of a historicity that no critical reading grounded in the search for harmonious elements can ever admit. As 'the archaic practices of an ancient 
environ erupt out of' (Keen 1998, 132) the contemporary present moment in Hardy’s novels, so also do instances of discursive insurgence arrive to interrupt and deform accepted norms of realist fiction. Identity, meaning, and ontology are haunted by their own 'alienated image[s]'. Hardy's characters, Hardy's locations, Hardy's plots manifest repeatedly 'pattern[s] of self-undoing' (Eagleton 2005, 195, 197). This just is history: an ineluctable, violent force, distorting and deforming any placid surface of the present, in the present, thereby making it impossible to reflect or represent ourselves with any calm assurance; impossible, that is, if we are not to engage in fictions that disingenuously deny the presence of the past. In this aletheic rupture that marks Hardy's writing, there is a sign that Hardy anticipates a certain modernist interest in mark, sign, fragment, ruin, and the role of memory in the subjective generation of narrative flux between past and present.

\section{Cultural Confrontations}

Of course, that Hardy has been misread, poorly read, not read at all, is suggestive of the estranging forces of historicity, historicality and anachronism within and on the form of English literature, so that certain readers remain blind to the codes and signs of their own cultures. That this is effected has, no doubt, to do with the belief that one can, in controlling the reception of the past, exorcise the more wayward phantoms from one's present. An element of critical negativity can be put down to contemporary cultural mores in the face of Hardy's, at the time, frank exploration of desire and sexual relations. For example, A Laodicean was criticized in the World magazine for what was taken to be the novel's 'carnal suggestiveness' (Anon., 1882, 18). During editorial consideration of The Woodlanders at the time of serial publication, the final sentence ending Volume II, Chapter IV, was excised on the grounds that it was too sexually explicit. The scene leading up to this moment involves 
Edred Fitzpiers, the young doctor living near the village of Little Hintock, and Suke Damson. The night is that of Midsummer's Eve, a particular folk ritual concerning the divination of future husbands having taken place in which Suke and other young women from the village engage. Running through the woods, Suke is chased by Fitzpiers. Catching her, he begins to kiss her and, 'they sank down on the next hay-cock' (W II.IV.150). The sentence censored from the serial provides the punctuation to this nocturnal scene: 'It was daybreak before Fitzpiers and Suke Damson re-entered Little Hintock’ (W II.IV.150).

There are many more such examples of moral censorship throughout Hardy’s career as a novelist, being a result of both editorial intervention and negative critical reception after publication. Such misreading of Hardy's works in his lifetime, as injurious as they were to Hardy personally, is commonplace enough. Yet, there was that other aesthetic response to form and language, diction and construction, and the perception that Hardy was straining after originality or effect, thereby allowing his rhetoric to get in the way of telling the story. Contemporary reviews of The Return of the Native make just such assertions. The Athenaeum compared Hardy with 'a person who has a keen eye for the picturesque without having learnt to draw'. Furthermore, his observation was 'disfigured at times by forced allusions and images'. Eustacia Vye is singled out for critical opprobrium, belonging 'to the class of which Madame Bovary is the type' (The Athenaeum, 23 November, 1878). This comparison with Flaubert is instructive, and The Athenaeum is not alone (presumably) in its cultural xenophobia. Going on to remark that 'English opinion' does not allow for the Bovary 'type' in the English novel, it anticipates a comment on the part of another reviewer, W.E. Henley, in The Academy a week later, who summarizes The Return of the Native as 'all very cruel, and very mournful, and very French’ (having already spoken of Hardy’s work as being contaminated by 'Hugoesque...insincerity'). The Saturday Review (4 January, 1879) also commented on the writers of the younger generation who 'scandalize traditional opinions'. 
Hardy is typical of this 'scandalous' behaviour in using 'eccentric forms of expression' along with 'similes and metaphors [that] are often strained and far-fetched', while the story 'strikes us as intensely artificial'. 'We are in England all the time', continues the offended reviewer, 'but in a world of which we seem to be absolutely ignorant'. This might just be the point for Hardy.

Criticizing the sexual frankness or openness of a Hardy novel is, inevitably, only the most obvious way of signalling an inability to read what is taking place, as well as staging a resistance to and avoidance of reading. It is a sign of being unseated from what one assumes as one's habitual cultural positions. What is telling from the foregoing criticisms of The Return of the Native is the native anxiety in the face of identities that trouble Englishness in its supposedly assured stability. Sexuality taken too far is foreign, distasteful. The takingplace of domestic sexuality is an historical threat that serves to figure the threat of a foreign otherness erupting in one's own national home. If the rural is a site of fecundity, this in the 1870 s is submerged within an economy of reproduction subservient to the production of foodstuff. Under the sign of an economic production, all reproduction in excess of such consumerist (or less commonly theological) narratives is radically disorientating. A second point, if we take the rural as either largely forgotten, or depoliticised and dehistoricized through the nostalgic and utopian idealisation of Morris, Arnold, Tennyson and others, is that sexuality rehistoricizes and repoliticizes the rural.

Moreover, sexuality threatens the implicit Englishness of the novel as form and idea. It traces a return of the repressed, an irrepressible difference that affirms itself. Inasmuch as the reviews feel identity to be threatened, this threat is perceived as not only foreign, though. Hardy's very Anglo-Saxon 'heart of darkness' is much closer to home. The very ontology of Englishness is in crisis, perceiving itself however indirectly as under threat in these reviews, as already noted. For Hardy is repeatedly criticised for the strangeness of his domestic, yet 
Introduction

not-quite-English rural inhabitants. The 'language of his peasants may be Elizabethan', remarks The Athenaeum, 'but it can hardly be Victorian’ (23 November, 1878). Having introduced the possibility of linguistic anachronism returning from some past to strike at modern identity, the review then goes on to remark on the artificial pitch of the dialogue: '[t]hese people all speak in a manner suggestive of high cultivation, and some of them intrigue almost like dwellers in Mayfair, while they live on nearly equal terms with the furzecutting rustics'. Class and location (dwellers in Mayfair and furze-cutting rustics, city and country) are inextricably traced here, in a psychic topography of English selfhood and alterity. Critique of dialogue makes the connection and, on Hardy’s part, the 'confusion' of form and genre, clear between the ontologies of cultural and literary identity, signalling in this manner the site from which it is issued. It is as if Hardy contaminates the novel in the last decades, Equally, it is as if criticism issued from the urban centre of nation and empire, the capital, stages in encrypted form the trauma of Englishness in its secret confession that an older, rural England, having been sacrificed to modernity, to urban-centred capitalist modes of production, can neither be remembered as an other to the modern nor re-imagined as vital, surviving.

Identity is also troubled in the confusion of locations from which language appears to come, and to which it may be assigned, as the implicit metropolitan incomprehension of rural subjectivities seems to suggest. This is echoed in The Saturday Review. Commenting on the 'unreal and unlifelike' names of Hardy's characters, the reviewer surmises that 'we doubt whether nine out of ten of them are to be met with in the pages of the London Directory. It is true that they may possibly be local for all we know to the contrary'. For all we know. Hardy's rural England is so foreign, so untimely, so other than the world as it is apprehended by metropolitan and urban critics in the 1870s and 1880s, that it baffles comprehension even as it assaults the supposed certainties of self from which location reading takes place. As the 
Times put it of The Return of the Native (5 December, 1878), 'we are transported...we feel rather abroad here, and can scarcely get up a satisfactory interest in people whose history and habits are so entirely foreign to our own' (emphases added).

The strange energy of Hardy's writing is such that it not only challenges critical mastery, but disturbs the critic to a degree that estranges the possibility of reading. More than this, though, the Times' commentary encapsulates a sense that the rural English are perceived as more wholly other than any more obviously 'foreign' culture. It is this strangeness of an English alterity tinged with anachronistic defamiliarization and, with that, the troubling depth of historical and temporal resonance, lost to the traumatic experience of modernity within Hardy's narratives of the English other, which amounts to an assault on Victorian selfreading from within the domestic space of literature. It is not that the rural English are simply at a remove geographically and therefore definable according to a set of paradigmatic models capable of incorporating difference within the self-same. Theirs is an otherness that will admit of no recuperation, and which, reciprocally, returns in Hardy's fiction to usurp the calm assurance of self-reading seeking a reflection or inflection of the self. Hardy's fiction presents us with both a return of the repressed, a revenant reiteration of the forgotten, and additionally, as the many lost signs of pagan and folkloric alterity and archaic historicity attest, the return(s) of the native.

Pausing to reflect for a moment, a strong reading of the title in the manner just implied is justified, if only because this other reading indicates that which, arguably in the title, is precisely that which contemporary reviewers miss. For, while on the one hand the title may be read as signifying Clym Yeobright's return-he is after all the 'native' of Egdon Heath who returns to his home only to find it unhomely, himself a haunting stranger estranged from the familiar — on the other hand, the strong reading is there to be invented. In every being, however modern, there are always the anachronistic signs of some other, of 
something 'native'. If we pursue the etymology of native, we find buried beneath the more modern sense of someone belonging to a particular country, the older sense, equivalent to the Anglo-Norman naïf, signifying someone born in a state of bondage or serfdom. There is, in the resonance of this older sense, the signification of a mark made on someone, a legal inscription that ties someone to a place.

In the strong reading of Hardy's title, it is this invisible trait, the sign of being bound that 'returns' to the modern subject, as a revenant call of the other, and with that the demands of one's native historicity as the imprimatur, a counter-signature of one's being, however modern one believes oneself to be. There is that which is hetero-affective within being; the native returns in and to Clym, despite his cosmopolitan experience. While on the surface, the 'call' is a conscious one to which Clym responds, and so returns, my strong reading argues for this as an unconscious demand that Hardy reads at work everywhere in cultural identity. From such a micrological reading to the larger issues at stake, we return to the more general tension noted above. So disquieting is this confrontation that its effects are displaced in the act of reading onto literary form, or, it is arguable, the very ontology of the literary itself. Criticizing narrative on the grounds of form, the excess of its modes of articulation, and an inability or refusal to perceive that excess, exaggeration, and formal play may just be taking place for reasons beyond the comprehension of the reviewer, hints at a problem not with the identity of the novel but with those broader cultural and historical identities assumed by the critic.

\section{Densities \& Deterritorialization}

Hardy's novels' intricacy and density, their patterns of doubling, 'and at times tripling and quadrupling', which structure the text and complicate the act of reading, thereby and in the 
process ‘forming themselves into a dense web’ (Hardy, ed. Wilson 1997, xxviii), result in 'the construction of...narrative, [where] repetition and circularity are...prominent features'. There emerges in Hardy, furthermore, 'a polyphony of different, even contrasting [narrative] voices’. (Hardy, ed. Page 1997, 23) On the one hand, engaging in more than merely formal patterning, such narrative experiment results in the rejection of 'absolutist notions of identity' (Hardy, ed. Wilson 1997, 24) and a proto-modernist exploration of the fragmentation of the self. On the other hand, Hardy's structural networks perform a 'recovery of the past both spatially and temporally’ (Hardy, ed. Page 1997, 27). Conventionally read by turns in the past as 'difficulty', ‘thematic ambiguity’ or 'stylistic awkwardness', Hardy’s narrative, rhetorical and poetic play weaves matrices out of which is engendered and enacted anamnesiac recovery and a means to assemble alternative English identities, albeit identities in ruins. When one contemporary reviewer observed, '[Hardy] is most ingenious in devising problems, and bringing his people into situations of a complicated nature' (Anon, in Page 1997, 404), he was noting, albeit inadvertently a distortion of realist representation in order that the signs of the past might be found to trace themselves through the screen of the present. Moreover, Hardy's interlacing of countless aspects and facets that go to comprise his narratives finds its echoes in both the formal levels of the text and their archival and encrypted preservation of disparate, heterogeneous literary, cultural and historical traces. Every Hardy text, it might be said, offers a singular archaeological formation, albeit one offering no possibility of the location of an origin for its particular form. (It might therefore be better perceived as archival rather than archaeological.) Hardy’s text displays repeatedly a rhizomic ingenuity, through a complex of endless interdependencies that are unavailable to any architectonic prioritization or ontological ordering. The patterns of tension and resistance to easy comprehension suggest that the more we seek a single narrative thread, the more we 
come to realise how each thread is interwoven into, shot through by, and generative of countless others.

To begin to glimpse the density of such generational weaving, consider another title, The Mayor of Casterbridge. Though an obvious point, it is a necessary to observe that the novel is not entitled Michael Henchard. Clearly the title addresses immediately, even as it presents, a certain identity, which is public, official, and therefore impersonal; naming an office, it is constructed, historical, political, social. The title names and gives form to a social position, a structure within which any appropriate subject may be located, and thereby endowed with limited agency. Naming public office and specular role, the mayoral post is a locus of civil organisation and power, to be filled by successive individuals. Henchard is merely a privileged agent of an already existing historical and cultural formation, occupying the position after countless others. Thus the title names simultaneously a social, a communal structuration, and a position which provides evidence of but one temporal thread, a continuum or stitch in the social and temporal weave of Casterbridge itself. The title is thus a site of contesting, and contested ideological and historical multiplicities, wherein are encoded iterable struggles.

Such staging of multiplicity reveals at the simplest level the intricacies of Hardy's text. What holds for the title is true also of the text in general. Indirectly, we can also understand, if not be in agreement with the reasons for, that critical desire to trace a single structure or ontology and thereby control the flows that inform, enunciate, and, it has to be said, deform the heterogeneous whole. A haunting excess irreducible to the very site from which such flows are glimpsed is read, as reading disrupts order and form. Yet, despite the complexities, there has existed a 'recurrent critical tendency' (Hardy, ed. Wilson 1997, xxv) to simplify textual relations. This act of simplification has demonstrated a propensity to reduce Hardy's significance as a novelist. Resisting such reductiveness, Terry Eagleton 
points to what we might describe as the 'problem of Thomas Hardy', the novelist's 'blunt disregard for formal consistency,...[his readiness to] articulate form upon form — to mingle realist narration, classical tragedy, folk-fable, melodrama, "philosophical” discourse, social commentary' (1981, 126). This attempted taxonomy at once points to the difficulty that criticism, grounded on formalist and aesthetic criteria, has had in making Hardy conform to a single model.

At the same time, though, Hardy's text resists critical acts of recuperation precisely because of its discursive heterogeneity, and is understandable as an 'always protean oeuvre' (Page 1998, 75). In its 'blunt disregard for formal consistency,...[and his readiness to] articulate form upon form-to mingle realist narration, classical tragedy, folk-fable, melodrama, “philosophical” discourse, social commentary’ (Eagleton 1981, 126); Such 'disregard' is, itself, the material registration of historicity on the text through its formal openness to heterogeneity and resistance to ontological stabilization, as well as being itself a response to particular historical and cultural conditions. This response is double: on the one hand, it has to do with the history of the novel, and the forms it takes in its development over the previous two centuries. Simultaneously and on the other hand, formal discursive, epistemological and ontological play (misread as 'fault' or 'failure') signals an equally material response to broader histories, beyond those of the novel, having to do with the mediation of cultural identity, the inheritance of the past, and a sense of destabilized, perhaps undecidable Englishness in Hardy’s historical moment as a novelist.

\section{Who's Afraid of Hardy?}

In conclusion, I want to turn to the matter of anxiety. Anxiety is undeniably significant, whether it is found in Hardy's texts or as an implicit motivating force in much of the critical 
Introduction

history of Hardy's reception. In her study of gender, subjectivity and corporeality, Marjorie Garson extends the critique of conventional critical methodology, suggesting that " $H a r d y "$, the realist novelist of “character and environment”, is himself a construction', a construction which has led to a distorted reading of the novels (Garson 1991, 1n.2). Connecting this misreading to anxiety, she argues that '[m]any of the instabilities, contradictions, and grotesqueries in the fiction...make considerable sense' when the novels are read as the exploration and expression of a 'somatic' anxiety about the dissolution of bodily identity (Garson 1991, 1). This can be argued to be the case whether the body is the human body, on which Garson focuses, or the figurative 'bodies' of buildings, the structures of towns, or the very landscape itself, perhaps even the 'body' of the novel itself. Whichever we address, ‘Hardy's fiction expresses certain anxieties about wholeness...in ways which are fairly consistent, though never simple or predictable' (Garson 1991, 3). The 'problem' of Hardy is therefore not primarily aesthetic. Rather, the question concerns the ways in which the materiality of the letter can disturb, leading one to question the epistemological grounds of representation.

Take ghosts, for example—and phantoms, spectres, spooks, revenants, apparitions, spirits, and every other 'species' of manifestation. Neither there nor not there, how are they to be read in Hardy's work? Are we to take them literally as phantasms, and if so, do they belong to the mind or to an external supernatural world? Is their alterity internal or external? Or both, crossing somatic, material, and psychic boundaries, returning unbidden, and always hovering in waiting, waiting to return to remind us that memory, one aspect of one's being, is a haunted location? Memory, that which we think of as most personally ours, is nothing other than this haunted house. I exist therefore I am haunted. Other questions obtrude, in the manner of unwelcome spirits: are we to take the ghosts in Hardy's texts literally or metaphorically, as prosopopoeic forms or figures of analogy (or all of the above?) Are we to 
see the work of haunting, conversely, in the interruption of the historical remnant? When, in a poem from Poems of the Past and Present, 'The Mother Mourns' (CP 111-114), the narrator, recollects, how when

\section{I fared Yell’ham-Firs way...dimly [there] \\ Came wheeling around me}

Those phantoms obscure and insistent

That shadows unchain. (ll. 5-8)

The poem resists easy accommodation of its scene. The reader cannot say with any certainty what is taking place, initially. Place appears to conjure the phantoms from shadows. In this there is already a doubling, a slippage between the immaterial aspects of the material world, the possibility that place is haunted, and the not unreasonable sense that all effects of 'midautumn' wind and shadow merely serve to produce an uncanny experience for the superstitious mind. From this point, however, the poem stages a wholly unnatural voice, that of the title’s mourning Mother: Nature. In 'aërie accents, / With dirge-like refrain', Nature bemoans how, having created human consciousness, she finds such consciousness distinctly 'unnatural'. In other words, humans exist inauthentically and have caused destruction, not being mindful of the true nature of dwelling. Nature is thus revealed as a phantom of sorts, but the anxiety of the 'mother's' complaint remains undecidable as to its origin or source. By the conclusion of the poem we are no closer to understanding whether this voice is that of the first narrator, 'externalised' as anthropomorphised Mother Nature, or whether there is a supernatural source for the voice; whether, in fact, the modern narrator has found himself somehow plunged into an atavistic pantheist universe. The strangeness of the poem does not desist, and there is no easy recuperation that reading can effect. In short, though, this destabilizing force is always at work in Hardy's writing, hence the anxieties that plague Hardy’s text and its reception. 
Through addressing different, yet interrelated strands of the manifestation of anxiety in Hardy, criticism acknowledges Hardy's ability 'to sustain...a multiplicity of causality' (Gatrell 1993, 3). Such multiplicity bespeaks submerged, 'partly concealed patterns'. Revealing submerged patterns suggests 'dangerous subversions of mode and ideology...which have been critically suppressed in favour of...the production of an “acceptable” Hardy’ (Fisher 1992, 1). However, if Hardy is never 'single-minded or wholly consistent', this only serves to make 'the experience of reading his fiction both rich and contradictory’ (Gatrell 1993, 6). There is, then, an aporetic experience in reading Hardy, an encounter with the undecidable, and a frankly incompatible or impossible confrontation of epistemologies that serve to produce the possibility of the impossible as the work of literature itself, which goes beyond notions of the 'contradictory'. Such experience is produced, if at all, in a reading that recognises the relationship in Hardy's writing between the materiality of the event, the material force of vision, the mediating, haunting power of memory, and, weaving between these, that spectral insistence.

All such forces have little to do with realism and the common perception of the constitution of nineteenth-century or Victorian fictional modes. Hardy's own disinterest in the constraints of mere realism stems from his rejection of 'realism' as art. Art should 'disproportion' the real in figuring, or rather disfiguring, 'distorting, throwing out of proportion...[the representation of] realities, to show more clearly the features that matter in those realities' (LTH 229) What is empirically observable, takes second place for Hardy to that higher, visionary mode of perception in the mind's eye: 'the seer should watch [one] pattern among general things which his idiosyncrasy moves him to observe...the result is no photograph, but purely the product of the writer's own mind' (LTH 153). What the mind's eye is capable of decoding from the merely real or material is simultaneously a matter of reception and deciphering. Moreover, it is not a question merely of opening oneself to hidden 
patterns but also to the otherwise invisible echoes of the past, which vision distorts and disproportions the present of the gaze even as it opens the self to the arrival of some phantasmic arrival or, more accurately, the trace of an historical other, as we shall see. Hardy's novels speak not so much from a single, identifiable voice as from some form of phantom narrating machine capable of translating into narrative or poetic form site, topography, trace, history, and collective memory. Acknowledging this, if the only 'true', uncontested detail in the doxa surrounding Hardy's literary output and its biographical contexts is that Hardy is an 'author', then Hardy, it might be said, remains to be read; 'some other's accent' remains to be heard, to be received, and answered. 


\section{Note}

i I use the terms 'dwell' and 'dwelling' specifically, following Martin Heidegger. Dwelling arises from how one lives on the earth, rather than being determined by the material structures one builds: ‘dwelling is the manner in which mortals are on the earth' (Heidegger 1993, 350). Building is what we do because we dwell on the earth, rather than being that which defines dwelling. For Heidegger, not having a true relation to the earth means that one is alienated from the truth of one's being. The Heideggerian 'fourfold' is the organic coalescence of earth and air (Hardy's landscapes and the subject's place within these), mortals (figured in Hardy through 'living memory' and those who had driven flocks and herds, as well as in the fairs and markets), and 'divinities'. It is not immediately clear where this last category might be located in Hardy, other than through vague rhetorical references to the fates or gods, or specifically in the passage quoted above. However, given that Heidegger speaks of the unconcealment or withdrawal of the divinities in thinking earth, air and mortal together in the 'simple oneness of the four' (1993, 352), I would read the dis-enclosure of the Heideggerian divinities in Hardy's sense of temporal dwelling and spatial perception. Merely visual or realist examination is transformed through visionary perception into an apperception of some immanent or transcendent force. Dwelling is thus perceived as that which perception maintains through the careful reading of the traces of the past, dwelling and being intimately enfolded in Hardy's narrative act of what Heidegger calls 'preserving', which 'keeps the fourfold in that with which mortals stay: in things’ (Heidegger 1993, 353). 